\title{
Experiments in the Sea on Rate of Growth of some Crustacea Decapoda.
}

$\mathrm{By}$

\author{
J. H. Orton, D.Sc.
}

With 2 Figures in the Text.

\section{Contents.}

Experimental Methods

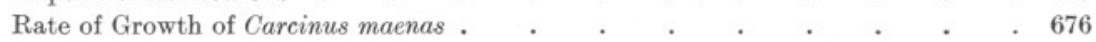

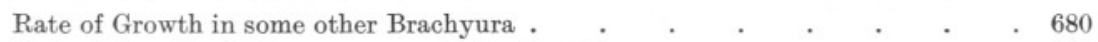

Rate of Growth of Cancer pagurus in the First Year . _ . . . . . . 681

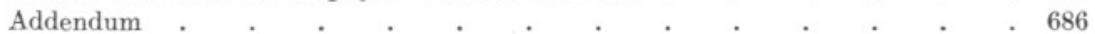

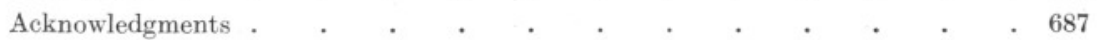

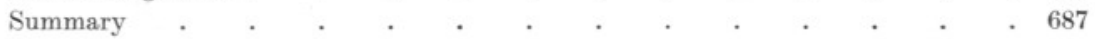

References

\section{Experimental Methods.}

In the course of studies on the rate of growth in marine animals by experiments and observations on material put in the sea at a known time, data on the rate of growth of a few Crustacea Decapoda have been obtained and are recorded in Table I. These experiments, except in two cases, were not designed for the purpose of following the rate of growth of Crustacea. The records obtained are nevertheless of value and may be compared with the heavy annual growth of sedentary organisms accompanying them (see 6, $\mathbf{7}$ and $\mathbf{8}$ especially); for example, Ciona intestinalis commonly $15 \mathrm{~cm}$. long, Ascidiella aspersa $7 \mathrm{~cm}$. long, Teredo sp. 5-6 cm. long, Sycon $9.5 \mathrm{~cm}$., Sabella pavonina with tube $36.5 \mathrm{~cm}$. long, and all sexually mature.

In all the experiments given in Table I, except Experiments 2 and 3, some kind of experimental apparatus with small openings, whether small wire mesh (see 8, Fig. 2, p. 10) or the circular holes in perforated zinc (see 6, Fig. 1, p. 241), was put out in the sea with experimental animals, and left in the sea for varying periods, but usually about one year. During this time various small animals either crept into the cage, or were washed in, and feeding on the contained or adjacent animals grew in situ too large to get out again. No doubt some crabs entered the cage at various times, grew larger and became imprisoned, but some may have crept into the cage as soon as it was put into the sea. The experiments theref ore can only give the rate of growth from the greatest possible size at 


\section{TABLE I.}

Experiments on Rate of Growth of some Decapoda.

\section{No. of Locality. \\ Expt. \\ 1 West Mersea \\ 2 Cawsand Bay, Plymouth$$
\text { do. }
$$

3 Cawsand Bay

do.

do.

do.

4 West Mersea do.

5\| River Yealm do.

6 West Mersea 7**River Yealm

do.

8 West Mersea

\begin{abstract}
No: of
larger
\end{abstract}

Species and maximum size (C.W.) in $\mathrm{mm}$. admitted to apparatus.
Carapace width or width $\times$ length in $\mathrm{mm}$. when taken from apparatus.

\section{Carcinus maenas, 23}

ิㅗ $36,34,32,26 \cdot 5$ 우 $31,25,20,15$

Maximum
time in
cage in
months.

Experimental

Apparatus hauled Maximum size of perforations of

months, apparatus examined. apparatus at put in sea. end of expt.

$3 \frac{3}{4}$

18.vi.13

$3 . x .13$

in $\mathrm{mm}$.

$15 \times 14^{*}$

Tray with perforated wire mesh lid

28.v.13 26.ii.14 $14.5 \times 9 \quad$ Wir average $11 \times 6$

do. do. $19 \cdot 5,19$

Por

Por

gicornis, $\$$ ca $7 \times 7$

persa, $6 \quad 10 \times 15$

Leander serratus, $\$ 6$

53

Hyas araneus

우 $25 \cdot 5 \times 38$

Carcinus maenas, $21 \cdot 2$

우 $31 \cdot 7$

Portunus arcuatus, ca 21 o $27 \cdot 5 \mathrm{soft}$

Portunus puber, ca 21 우 28.0

Hyas araneus

28.0

Cancer pagurus, 21

오 $49 \cdot 7 \times 31 \cdot 6 ; 074 \cdot 4 \times$

$30 \cdot 1$

5 Portunus arcuatus,

ca 21

of $25 \cdot 5 ;$ † $27,24 \cdot 9$, $22 \cdot 3,21 \cdot 3$

12 Carcinus maenas, 16

Description

opparatus.

9.vii.24 2.vii.25

$10 \times 10$

do.
के $37 \times 29,22.4 \times 17.2$, $20.8 \times 16.0, \quad 17.2 \times$

$14.0,10.0 \times 8.0$

ㅇ $37 \times 29,34 \times 27,23.8$

$\times 18.0, \quad 25.5 \times 21.0$

$20.5 \times 16.0, \quad 21.0 \times$

$17 \cdot 0,15 \cdot 4 \times 12.6$ 
do.

do.

do.

9 West Merses

10 West Mersea

1 West Mersea

do.

12 River Yealm

do.

do.

do.

13 Morecambe Bay

\section{ea 1}

Macropodia sp., ca 16蛙

Hyas araneu.

Hyas sp. $\S$

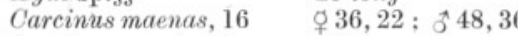

Carcinus maenas, few $\quad$ 31 , young ova

ơ $32 \times 15$

우 $15.5 \times 24$

oิ 43,42

Carcinus maenas, 1

Cancer pagurus, $17 \cdot 5$

온 57

Carcinus maenas, ca $7 \cdot 0 \quad 23 \cdot 2$ (cast shell $17 \cdot 2$ )

$11 \frac{3}{4}$
$11 \frac{3}{4}$
$11 \frac{3}{4}$
$11 \frac{1}{2}$
$11 \frac{1}{2}$
$11 \frac{1}{2}$
$10 \frac{1}{4}$
$10 \frac{1}{4}$
$2 \frac{3}{4}$

do.

do.

do.

do.

3 do.

do.

do.

우 $23 \cdot 2$; శึ $25 \cdot 4,24 \cdot 2$

우 $30 ;$ ơ 25

우 $29 ;$ ơ 31

Carcinus maenas, $4 \cdot 5 \quad$ † $22 \cdot 8 ;$ oิ $26 \cdot 0$

$\begin{array}{lll}\text { do. } & 2 & \text { do. } \\ \text { do. } & 4 & \text { do. } \\ \text { do. } & 2 & \text { do. }\end{array}$

\section{오 $31 \cdot 0 ;$; $11 \cdot 5$}

of $44 \cdot 6$; of 35.9 with

Sacculina

o $44 \cdot 7$ in berry ; ơ $31 \cdot 0$

$11 \frac{3}{4}$
$11 \frac{3}{4}$
$11 \frac{1}{2}$
$11 \frac{1}{2}$
$11 \frac{1}{2}$
$10 \frac{1}{4}$
$10 \frac{1}{4}$
$2 \frac{3}{4}$

do.

do.

21.vii.25

do.

do.

do.

3.vii. 26

do.

do.

do.

$10 \times 10$

do.

21.vii.25 5.vii.26

few

Wire cage

do.

Basket

suspended

14.vii. $26 \quad 26 . v .27$

do.

do.

$10 \times 10$

do.

Wire cage

16.viii.19 10.xi.19

6 diam.

do.

Experimental

box of per-

forated zine

$\begin{array}{lcc}6 \frac{1}{2} & \text { do. } & \text { 5.iii.20 } \\ 8 \frac{1}{4} & \text { do. } & 21 . i v .20 \\ 9 & \text { do. } & 19 . v .20 \\ 2 \frac{1}{2} & \text { 15.vii.33 } & 3 . x .33\end{array}$

* This mesh was the largest used and would permit entry of a crab about $23 \mathrm{~mm}$. C.W., the age of which from liberation as a zoea may be estimated at a maximum of four months.

$\dagger$ The apparatus rested against the bottom and sides of a floating raft on which a good growth of seaweeds and animals was available for food (see ${ }^{\text {y) }}$.

¥ The records of Leander serratus are given, although their value may not be great. Relatively large prawns would be able to enter the cage in Experiment 2 at any time, and under the urge of finding food may be able to squeeze through a relatively small hole. On similar grounds the records of Porcellana longicornis and Galathea dispersa must be accepted with reservations.

$\S$ This experiment was concluded hurriedly during the war and no record made of the size of the perforations; these were however small and certainly not greater than $6 \mathrm{~mm}$. in diameter.

\| One P. puber $\sigma^{\star} 19 \cdot 1$ C.W. was also found in the cage 10.v.1923.

** On 24.vi.1924 the cage was cleared when the following animals were removed: Cottus bubalis 88 to $98 \mathrm{~mm}$. long; C. maenas 26 mm. C.W.; Galathea squamifera 우 15, ơ $14 \cdot 2,13 \cdot 3 \mathrm{~mm}$. C.W.; Calliostoma zizyphinus shells $16 \cdot 0$ to $21 \cdot 8 \mathrm{~mm}$. wide ; Botrylloides rubrum colony $70 \times 60$ mm.; Botryllus violacea colony $95 \times 45 \mathrm{~mm}$. On $26 . \mathrm{vi} .1925$ the following animals were also taken: P. arculatus O's in berry $19 \cdot 6$, $19 \cdot 4,18 \cdot 9,18 \cdot 2$, $16.0 \mathrm{~mm}$. C.W.; Galathea squamifera $015, \mathrm{o}^{\prime} \mathrm{s} 14 \cdot 2,13.3 \mathrm{~mm}$. C.W., but this species might enter the cage at a C.W. of about $15 \mathrm{~mm}$.

t† Identified at sight in the field and not afterwards confirmed, but probably correct.

\# Probably Macropodia phalangium.

$\S \S$ Probably Hyas araneus. 
immediate entry to the size when recovered from the cage. This is, however, the maximum time required for the growth observed. Although there is good reason to believe that immediate permanent entry at the maximum size was not often made during the experiments as food material would not always then be available, it was nevertheless always possible. For these reasons it is probable that the crabs and prawns obtained in the cages had rarely spent the whole possible period in the apparatus, and that the rate of growth in the open sea may be greater than that indicated by the experiments.

In Experiments 2 and 3 cages made of iron wire mesh or perforated zinc were fitted into a large floating raft (see $\mathbf{7}$, p. 399) which was covered with heavy growths of marine organisms (see 5, p. 318). Food was therefore available from the outset for such animals as crept into the boxes.

The size of the greatest mesh was always noted at the end of the experiment, and if greater than at the beginning was so recorded. Usually the mesh became slightly smaller, but some meshes may be opened accidentally. (See Table I, Expt. 2.)

The probable age of the experimental crabs may be obtained by an allowance of time made from Lebour's (3) and Shen's (13) rearing experiments. Lebour states, in general, that "the usual time for reaching the first crab stage seems to be about three weeks to a month, judging from rearing experiments. In natural surroundings it may be less. After the first crab stage the skin is cast about once a week for the first month, after which there are longer intervals, until at about four months old it begins to change once a month or more. Temperature seems to affect them, for in winter the changes were very slow." The carapace widths of fourth stage crabs (i.e. at an age of two months or less from hatching) obtained by Lebour are: P. puber $7 \cdot 36 \mathrm{~mm}$., C. maenas $4 \cdot 2 \mathrm{~mm}$., C. pagurus $6.7 \mathrm{~mm}$. Shen (13) finds the mean to be $4.4 \mathrm{~mm}$. for the fourth stage of $C$. maenas. It is noteworthy that in the corresponding early crab stages $C$. pagurus is larger in carapace width than C. maenas.

The rate of growth of marine animals in aquaria is usually slower than in the sea where information is available for comparison. Therefore both the rearing experiments and the records given in Table I give probably slower inferential rates of growth than occur in normal life.

\section{Rate of Growth of Carcinus maenas.}

From the experiments recorded in Table I an approximation can be made to the natural minimal rate of growth of Carcinus maenas. Shen (13) has recently reared in the Plymouth Laboratory the early stages of 12 male and 10 female post-larval crabs from the megalopa at the following mean periods in days and mean sizes in $\mathrm{mm}$. Carapace width $(=\mathrm{C}$.W. $)$ for males and females combined is shown in Table II. 


\section{TABLE II.}

\section{Data From Shen's wORK on post-LaRval $C$. maenas.}

\begin{tabular}{|c|c|c|c|c|c|c|c|c|c|}
\hline Stage & I.* & II. & III. & IV. & V. & VI. & VII. & VIII. & IX. \\
\hline $\begin{array}{l}\text { Mean C.W. in mm. } \\
\text { Mean period between }\end{array}$ & 1.84 & $2 \cdot 58$ & $3 \cdot 43$ & $\begin{array}{r}4 \cdot 41 \\
14 \text { to }\end{array}$ & $5 \cdot 83$ & $7 \cdot 92$ & $10 \cdot 3$ & $13 \cdot 5$ & $18 \cdot 23$ \\
\hline ecdyses in days & $7 \cdot 5$ & $12 \cdot 5$ & $14 \cdot 0$ & $19 \cdot 0$ ? & $17 \cdot 5$ & $18 \cdot 5$ & $14 \cdot 5$ & $14 \cdot 0$ & $14 \cdot 5$ \\
\hline $\begin{array}{l}\text { Mean accumulative } \\
\text { period in days }\end{array}$ & $7 \cdot 5$ & $20 \cdot 0$ & $34 \cdot 0$ & $\begin{array}{l}48 \text { to } \\
53 \cdot 0 ?\end{array}$ & $\begin{array}{l}65 \cdot 5 \\
70 \cdot 5\end{array}$ & $\begin{array}{l}83 \cdot 0 \\
88 \cdot 5\end{array}$ & $\begin{array}{r}98 \cdot 0 \\
103 \cdot 0\end{array}$ & $\begin{array}{l}112 \cdot 0 \\
117 \cdot 0\end{array}$ & $\begin{array}{l}126 \cdot 5 \\
131 \cdot 5\end{array}$ \\
\hline $\begin{array}{l}\text { Minimum accumula- } \\
\text { tive period in days } \\
\text { Mean increment }\end{array}$ & $4 \cdot 5$ & $15 \cdot 5$ & $24 \cdot 5$ & $36 \cdot 0$ & $46 \cdot 5$ & $60 \cdot 5$ & $71 \cdot 0$ & $82 \cdot 0$ & $94 \cdot 5$ \\
\hline in C.W. for o \& 우 & $61 \cdot 0$ & $41 \cdot 5$ & $34 \cdot 5$ & $31 \cdot 0$ & $31 \cdot 5$ & $31 \cdot 5$ & $31 \cdot 5$ & $32 \cdot 0$ & 3 \\
\hline
\end{tabular}

The last-mentioned minimum period is in reality a mean of the shortest periods between successive moults of those males and females which moulted most quickly in each stage. The shortest total period from megalopa to Stage VIII was 108 days for a male and 102 days for a female, that is, about $3 \frac{1}{2}$ months ; to Stage IX, 122 days for a male and 119 days for a female, that is, about 4 months. The average period of individual development from megalopa to Stage VIII was 117 days for 10 males and 114 days for 10 females, and to Stage IX, 125 days for 3 males and 120 days for 3 females. The average period for each stage is plotted against size in Figure 1, and an imaginary Stage $\mathbf{X}$-assuming continuance of the same kind of increment in carapace width and moulting period as occurs in Stages VII to IX-is plotted at A.

On the basis of the work of Shen the maximum age of the small crabs entering the cages in Experiments 13, 12 and 3 has been estimated and entered in Table III, column 3.

TABLE III.

RATE OF Growth of Carcinus maenas.

2

3

4

5 6
Maximum
period of

\begin{tabular}{|c|c|c|}
\hline $\begin{array}{l}\text { No. of } \\
\text { Expt. }\end{array}$ & $\begin{array}{l}\text { Maximum } \\
\text { width } \\
\text { at entry. }\end{array}$ & $\begin{array}{c}\text { Estd. ag } \\
\text { of (2). }\end{array}$ \\
\hline $\begin{array}{l}13 \\
\text { do. } \\
12\end{array}$ & $\begin{array}{l}4.5 \mathrm{~mm} . \\
\text { do. } \\
7 \cdot 0\end{array}$ & $\begin{array}{l}1 \frac{1}{2} \mathrm{~m} . \\
\text { do. } \\
2\end{array}$ \\
\hline 3 & $7 \cdot 0$ & 2 \\
\hline 13 & $4 \cdot 5$ & $1 \frac{1}{2}$ \\
\hline 1 & $23 \cdot 0$ & ca 4 \\
\hline 11 & 16.0 & 3 \\
\hline 13 & $4 \cdot 5$ & $1 \frac{1}{2}$ \\
\hline do. & do. & do. \\
\hline 13 & $4 \cdot 5$ & \\
\hline
\end{tabular}

Width at Minimum end of increment growth in expt. in width. at end oิ $26 \cdot 0 \mathrm{~mm} \cdot 21 \cdot 5 \mathrm{~mm}$. 우 $22 \cdot 6 \quad 17 \cdot 1$ ô $23 \cdot 2 \quad 16 \cdot 2$

우 $22 \cdot 5 \quad 15 \cdot 5$

우 $31 \cdot 0 \quad 26 \cdot 5$

ô $36 \cdot 0 \quad 13 \cdot 0$

ô $48 \cdot 0$

우 $44 \cdot 6$

$32 \cdot 0$

St $40 \cdot 1$

$13 \quad 4.5$

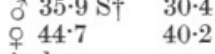

Cage

Expts.

West

in berry

expt. of expt.

$\begin{array}{ccc}2 \frac{1}{2} \mathrm{~m} . & \begin{array}{c}4 \mathrm{~m} . \\ \text { do. }\end{array} & \begin{array}{c}\text { May-June } \\ \text { do. }\end{array} \\ 2 \frac{3}{4} & 4 \frac{3}{4} & \text { June-July } \\ 3 & 5 & \text { April-May } \\ 5 & 6 \frac{1}{2} & \text { May-June } \\ 3 \frac{3}{4} & 7 \frac{3}{4} & \text { Feb.-Mar. } \\ 10 \frac{1}{4} & 13 \frac{1}{4} & \text { April. } \\ 14 \frac{1}{2} & 16^{*} & \text { May-June } \\ \text { do. } & \text { do.* } & \text { do. } \\ 19 \frac{3}{4} & 21 \frac{1}{4} * & \text { do. }\end{array}$

Mersea

$\begin{array}{llll}16 \cdot 0 & 3 & \text { ㅇ } 37 \cdot 0 & 21 \cdot 0 \\ & & 53 \cdot 0 & 37 \cdot 0\end{array}$

$37 \cdot 0$

* Age probably overestimated, see p. 679 .

$\begin{array}{ccc}12 & 15 & \text { April } \\ \text { do. } & \text { do. } & \text { do. }\end{array}$

$\dagger$ With Sacculina. 


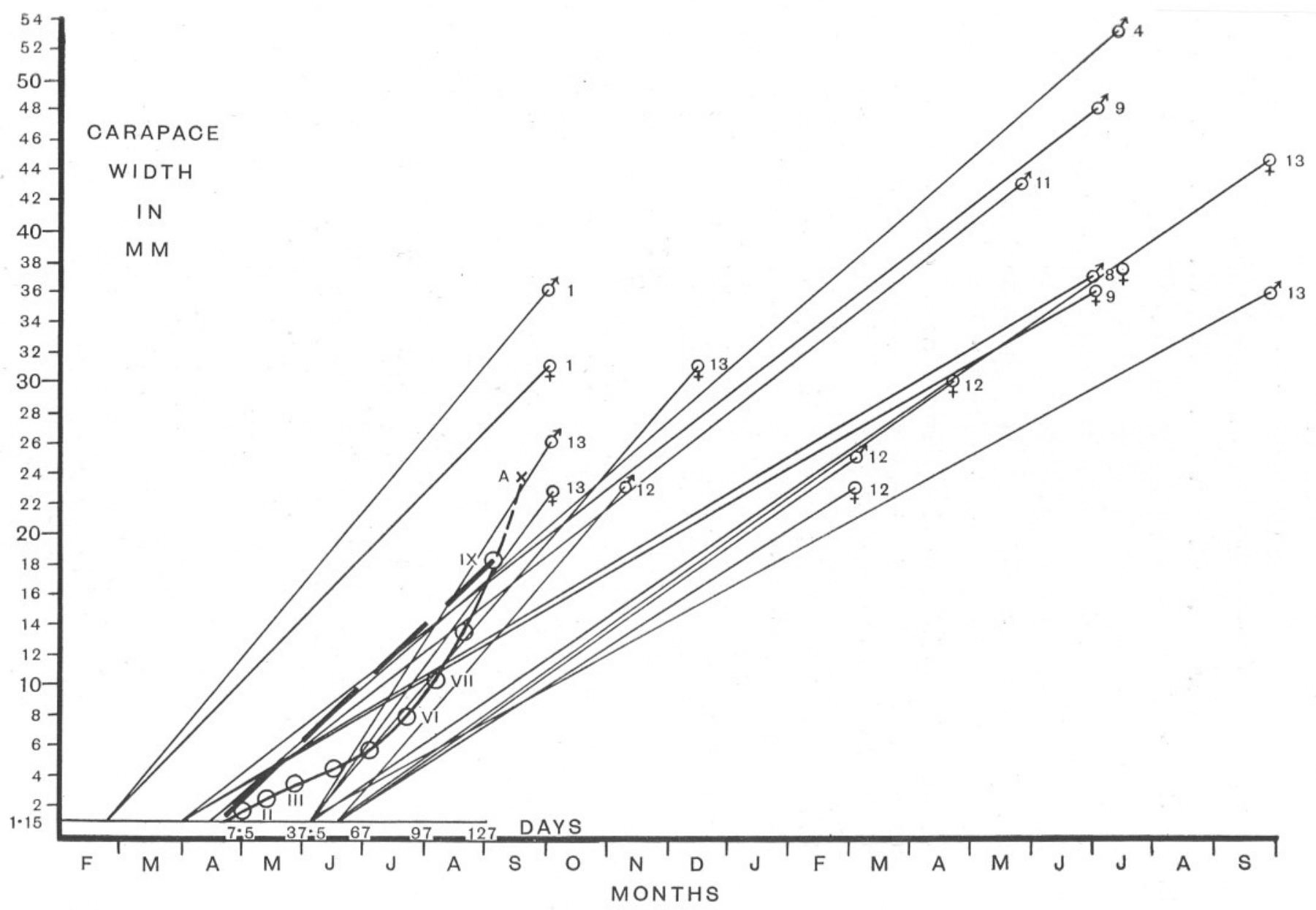

Fig. 1.-Graphs of mean minimal rate of growth of Carcinus maenas obtained in experimental apparatus in the sea, compared with rate of growth in the laboratory of post-larval Stages I to IX as obtained by Shen (13). (Carapace widths in mm. are plotted as a criterion of size.) The figures refer to number of experiment in Table I p. 674, and Shen's Stages I to IX (plotted for mean accumulative growth in days) are denoted by large circles. An imaginary Stage $\mathrm{X}$ is plotted at $\mathbf{A}$. 
The largest sizes at entry are given in carapace widths (C.W.) in column 2 of the same table with the maximum sojourn in the cage (column 6) and size at end of this period (column 4). The age at this latter size (column $3+6$ ) is given in column 7 .

From this analysis of the experimental data it is seen that Carcinus may attain in the first summer of growth a C.W. of at least $26 \mathrm{~mm}$. for males and $23 \mathrm{~mm}$. for females in 4 months; $31 \mathrm{~mm}$. for females in $6 \frac{1}{2}$ months ; $36 \mathrm{~mm}$. for males in $7 \frac{3}{4}$ months. In Experiment 13 a female $44.6 \mathrm{~mm}$. was obtained at a maximum age of 16 months, and a female in berry $44 \cdot 7 \mathrm{~mm}$. C.W. at a maximum age of $21 \frac{1}{4}$ months, but these two crabs were probably little more than 12 months old. In the annual experiments with the West Mersea oyster cage, extending usually from July to July, males commonly attained a width of 36 to $48 \mathrm{~mm}$., although one male $53 \mathrm{~mm}$. was taken, and females 31 to 37 . The maximum age of these males and females is about 15 months. These individual results are plotted in Figure 1 to show the minimal rate of growth, i.e. assuming that crabs entered the cages at a maximum size as soon as the apparatus was put in the sea, and an allowance made for age at entry based upon Shen's laboratory experiments. The slopes of the graphs represent mean rate of growth and are very variable, due first to unknown date and size of entry and secondly to unknown decrease in rate of growth in the winter period. The acceleration in growth of Shen's crabs with time is well shown and if continued (as at A) would give a mean rate of growth-indicated by the slope of the graphs-not very different from the experimental results. It may be therefore that the rate of growth found by Shen does not fall far short of that found in nature.

The experiments therefore prove that both males and females may attain a C.W. of 3 to $4 \mathrm{~cm}$. in the same year as they are spawned as zoeas, if the spawning is early, i.e. about February-March. Liberation of zoeas occurs in Carcinus in spring and early summer, although berried females and planktonic zoeas occur all the year round at Plymouth (Lebour, 3). Somewhat similar breeding periods probably occur in the Thames and Morecambe Bay areas with restriction of breeding in the winter months. There will thus .occur a great variation in size of crabs less than one year old at the end of any one breeding season. Nevertheless the minimal increments of growth occurring in the boxes with perforated zinc sides and top, e.g. for males $21.5 \mathrm{~mm}$. from $4.5 \mathrm{~mm}$. in $2 \frac{1}{2}$ months, for females $17.1 \mathrm{~mm}$. from $4.5 \mathrm{~mm}$. in $2 \frac{1}{2}$ months, $15.5 \mathrm{~mm}$. from $7.0 \mathrm{~mm}$. in 3 months, $26.5 \mathrm{~mm}$. from $4.5 \mathrm{~mm}$. in 5 months, indicate that sizes of 3 to $4 \mathrm{~cm}$. at least will be attained in 12 months by males and females whatever be the period of the year the zoea is liberated. This conclusion is substantiated by the experiments in the wire mesh oyster cages where males increased in C.W. in one instance $37 \mathrm{~mm}$. and in several other experiments from 20 
to $32 \mathrm{~mm}$. from $16 \mathrm{~mm}$. ; females increased about $20 \mathrm{~mm}$. from $16 \mathrm{~mm}$. in a period of at the most 12 months.

It is unlikely that the crabs found in the cages put out in July were second year individuals except in the probably remote occurrence of arrested growth. The experiments also indicate that the rate of growth is greater in males than in females.

Experiment 13 affords evidence that sexual maturity in the female is attained in the second summer at an age of not much more than 12 months; males probably mature at about the same age or earlier. These results show that in the sea more rapid growth occurs than in the interesting experiments on growth in captivity carried out by Waddington and Williamson (14). The latter writer concluded from his work that $C$. maenas attained a size (C.W.) of 8 to $22 \mathrm{~mm}$. in the first year; males $45-56 \mathrm{~mm}$. and females $35-48.5 \mathrm{~mm}$. in the second year; and males 60 , females $55 \mathrm{~mm}$. in the third year. Shen's work as well as the experimental results given here show that growth in the first year is much greater than was estimated by Williamson. Similarly second year growth is also greater in the sea than was found in laboratory crabs, but the discrepancy is probably not so great as in the estimate for the first year. There is no information regarding growth in the sea at the end of two and three years, but there is some indication that although growth may be slower in the early stages of this species in captivity than in the sea, in the later stages growth in captivity may not differ much from that in the sea.

Williamson records the spawning of a female at an age of less than two years old although reared in captivity, an observation that accords well with the record of the gravid female in Experiment 13 herein, at a maximum age of about 21 months, but at a probable age of little more than 12 months.

It seems probable that in Experiment 13 there was a constant excess of food-material available as on the ground outside (see 9, page 100), so that growth in this apparatus is likely to be closely comparable with that on the adjacent beds. In other experiments it is more difficult to assess the food-conditions and although there was probably a good supply in most cases, it is possible that at times there was less inside the apparatus than on the adjacent feeding grounds. For these reasons it is possible that the experimental results may, except in Experiment 13, give lower growth rates than would occur under natural free-living conditions.

\section{Rate of Growth in some other Brachyura.}

Experiment 2 demonstrates a growth in at most 9 months in Portunus puber from at most $18 \mathrm{~mm}$. to $35 \mathrm{~mm}$. C.W. in a male and to $33 \mathrm{~mm}$. in a female. In Portunus corrugatus a male attained a C.W. of $36 \mathrm{~mm}$. from at 
most $16 \mathrm{~mm}$. in at most $11 \frac{3}{4}$ months. The rate of growth in these species is therefore in all probability comparable in the first year with that of C. maenas. The few records of Portunus arcuatus in Experiments 5 and 7 are less valuable, as the species is relatively small and entry into the cage could be made at a relatively large size at any time. The actual incremental growth proved in these cases is slight. There is, however, good probability that this species reaches sexual maturity in one year.

Hyas araneus, female, occurred in Experiment 4 at a carapace width of $25.5 \mathrm{~mm}$. and length of $38 \mathrm{~mm}$. The maximum size of entry of this species was not determined, but would probably be a carapace width of 14 to $16 \mathrm{~mm}$. Smaller Hyas were taken on other occasions. It is not unlikely that a carapace length of about $4 \mathrm{~cm}$. is attained by this species in one year.

Macropodia sp., male, of a carapace length of $32 \mathrm{~mm}$. and width of only $15 \mathrm{~mm}$. was taken in Experiment 8, but is of more value as an indication of the experimental potentialities than as a definite growth record.

\section{Rate of Growth of Cancer pagurus during the First Year.}

The records given in Table I, Experiments 7 and 11, of the growth of the edible crab, Cancer pagurus, during early life are of considerable value, as little of a definite nature is known of growth during this period. Lebour has found (3) that megalopæ of this species occur in the Plymouth district during spring and early summer, and that among Brachyura in general the usual period from hatching to the first crab stage is three to four weeks in rearing experiments, but probably less under natural conditions. Young Cancer may therefore begin to settle in the Plymouth district in late spring or early summer. Similar breeding conditions probably occur in the Thames Estuary, with possibly rather later appearance of young crabs there and in more northerly situations. There is, therefore, good probability that the Cancer found in the Yealm and West Mersea experimental apparatus entered the cages as young post-larval crabs in the summers when the cages were put in the sea.

The possibility that the crabs found had wintered from the previous spawning season as very small individuals must also be considered, as Williamson observed (see Fig. 2, p. 684 herein) that small crabs of 1 to $2 \mathrm{~cm}$. (C.W.) occurred on the Scottish foreshore (Dunbar) all the year round; moreover, with the extended breeding season of this crab a wide range in size of one year individuals will undoubtedly occur. There are, however, two additional sources of information available on the growth of Cancer in the first year.

In the first instance young Cancer pagurus have been found year after year in October on the under side of bathing rafts put out in Plymouth 
TABLE IV.

Sizes of Cancer pagurus found on Bathing Rafts and Buoys in Plymouth Sound.

\begin{tabular}{|c|c|c|c|c|}
\hline $\begin{array}{l}\text { Raft }^{1} \text { or buoy } \\
\text { put out. }\end{array}$ & $\begin{array}{l}\text { Raft or buoy } \\
\text { brought in. }\end{array}$ & $\begin{array}{l}\text { Months } \\
\text { in sea. }\end{array}$ & $\begin{array}{l}\text { Total* } \\
\text { crabs. }\end{array}$ & Less than 20 \\
\hline April 30,1913 & Oct. 13,1913 & $5 \frac{1}{2}$ & 3 & 2 \\
\hline April $3,1912^{2}$ & March 5, 1913 & 11 & 1 & - \\
\hline May $14,1913^{3}$ & May 8,1914 & 12 & 2 & - \\
\hline April 20, 1914 & Nov. 12,1914 & $6 \frac{3}{4}$ & 5 & 1 \\
\hline May 2, 1919 & Oct. 10,1919 & $5 \frac{1}{4}$ & 1 & - \\
\hline April 28, 1920 & Oct. 12,1920 & $5 \frac{1}{2}$ & 2 & 1 \\
\hline April 27, 1920 & Oct. 13,1920 & $5 \frac{1}{2}$ & 25 & 12 \\
\hline April 11, 1921 & Oet. 14,1921 & 6 & $\infty$ & several $\ddagger$ \\
\hline April 13,1921 & Oct. 14,1921 & 6 & 5 & 4 \\
\hline April 19,1923 & Oct. 13,1923 & $5 \frac{3}{4}$ & 1 & 1 \\
\hline May 5, 1924 & Oct. 13,1924 & $5 \frac{1}{4}$ & $\infty$ & several§ \\
\hline April 18,1928 & Oct. 14,1928 & 6 & 2 & $?$ \\
\hline
\end{tabular}

* Excluding in many cases small ones not recorded. $\dagger \mathrm{s}=$ soft-shelled crabs.

* Many less than $22 \mathrm{~mm}$.

$\S$ Many less than $20 \mathrm{~mm}$.

$$
\begin{array}{cccccccccccc}
\multicolumn{10}{c}{\text { Cancer pagurus : Carapace width in mm. }} \\
20 & 21 & 22 & 23 & 24 & 27 & 28 & 29 & 32 & 34 & 39 \\
1 & - & - & - & - & - & - & - & - & - & - \\
- & - & - & - & - & - & 1 & - & - & - & - \\
- & - & - & - & 1 & 1 & - & - & - & - & - \\
- & 1 & - & - & - & - & - & 1 & 1 s \dagger & - & 1 s \dagger \\
1 & - & - & - & - & - & - & - & - & - & - \\
- & - & - & 1 & - & - & - & - & - & - & - \\
2 & 4 & - & 5 & 2 & - & - & - & - & - & - \\
- & - & 1 & - & - & - & - & - & - & - & - \\
- & - & 1 & - & - & - & - & - & - & - & - \\
- & - & - & - & - & - & - & - & - & - & - \\
1 & - & - & - & - & - & - & - & - & - & - \\
- & - & - & - & - & - & - & & 1 s \dagger & 1 & -
\end{array}
$$

1 All rafts unless otherwise stated.

2 No. 12 buoy, G.W.R. Docks.

${ }^{-3}$ No. 10 buoy, G.W.R. Docks. 
Sound in or about April. The sizes attained by these young individuals are recorded in Table IV and range from $8 \mathrm{~mm}$. to $39 \mathrm{~mm}$. in breadth of carapace. These rafts are treated on the under surface with a thick layer of well dried pitch, which permits of immediate settlements of growths such as barnacles, mussels, ascidians, hydroids, sponges and amphipods with an abundant micro fauna and flora. Ample opportunities are thus afforded for the settlement and feeding of young crabs, but it is unlikely that growths are sufficiently established for settlement before about June. As, however, the rafts are buoyed with mooring chains, it is not impossible for crabs to crawl up to the bottom of the raft along the links of the chain and across the swivel or shackle. For this reason these records have not the same value as those from the experimental cages; nevertheless the constant occurrence year after year of young crabs and only young crabs on these rafts gives probability to their growth in situ.

The probability that young Cancer 20 to $40 \mathrm{~mm}$. broad in OctoberNovember are the young of the current year is supported by the definite records given above and also by Williamson's well-known observations on beach crabs at Dunbar (15). Lebour also reared a crab in the laboratory to $14 \mathrm{~mm}$. C.W. on November 30 from a megalopa moult on July 7 . This growth may be regarded as probably slower than natural. The Dunbar beach crabs give the second class of data on rate of growth in the first year.

Williamson's data are given in Table V (p. 685) and Figure 2 (p. 684) in a different form from the original. The monthly collection of crabs have been assembled in $\mathrm{cm}$. groups and plotted as a percentage of the monthly catch. The collections were begun in October, 1897, and continued regularly until September, 1898. The course of the graphs shows clearly that an influx of young crabs 2 to $3 \mathrm{~cm}$. occurred on the foreshore in August, 1898, and that these crabs showed a modal value of 2.5 to $3.5 \mathrm{~cm}$. in September 1898 . The modal value $3.5 \mathrm{~cm}$. in October, 1897, is in accordance with the trend of growth in August and September, 1898, and is comparable with the seasonal growth of C. maenas. The graphs from October, 1897, onwards indicate a stationary modal value until March, 1898, when it rose to 4.5 and was apparently maintained until as late as July. In May, however, a relatively high proportion of crabs 5 to $6 \mathrm{~cm}$. was found and it is conceivable that an offshore migration began soon afterwards. Williamson suspected such a migration and set pots close inshore later (19001901) to obtain information. His results in a modified form in approximately $\mathrm{cm}$. groups are included in Table $\mathrm{V}$ (excluding breadths above $12 \mathrm{~cm}$.). By these investigations he proved that although crabs belonging to the $5 \mathrm{~cm}$. group are relatively scarce, those belonging to the $6-, 7-;, 8$ and 9-cm. groups occurred close inshore in good numbers in May, 1901, and 
in June, July and August, 1900. These along with the beach observations lend support to the probability of a migration from the beach at a size of $5 \mathrm{~cm}$. and as early in the life history as about the end of the first year of

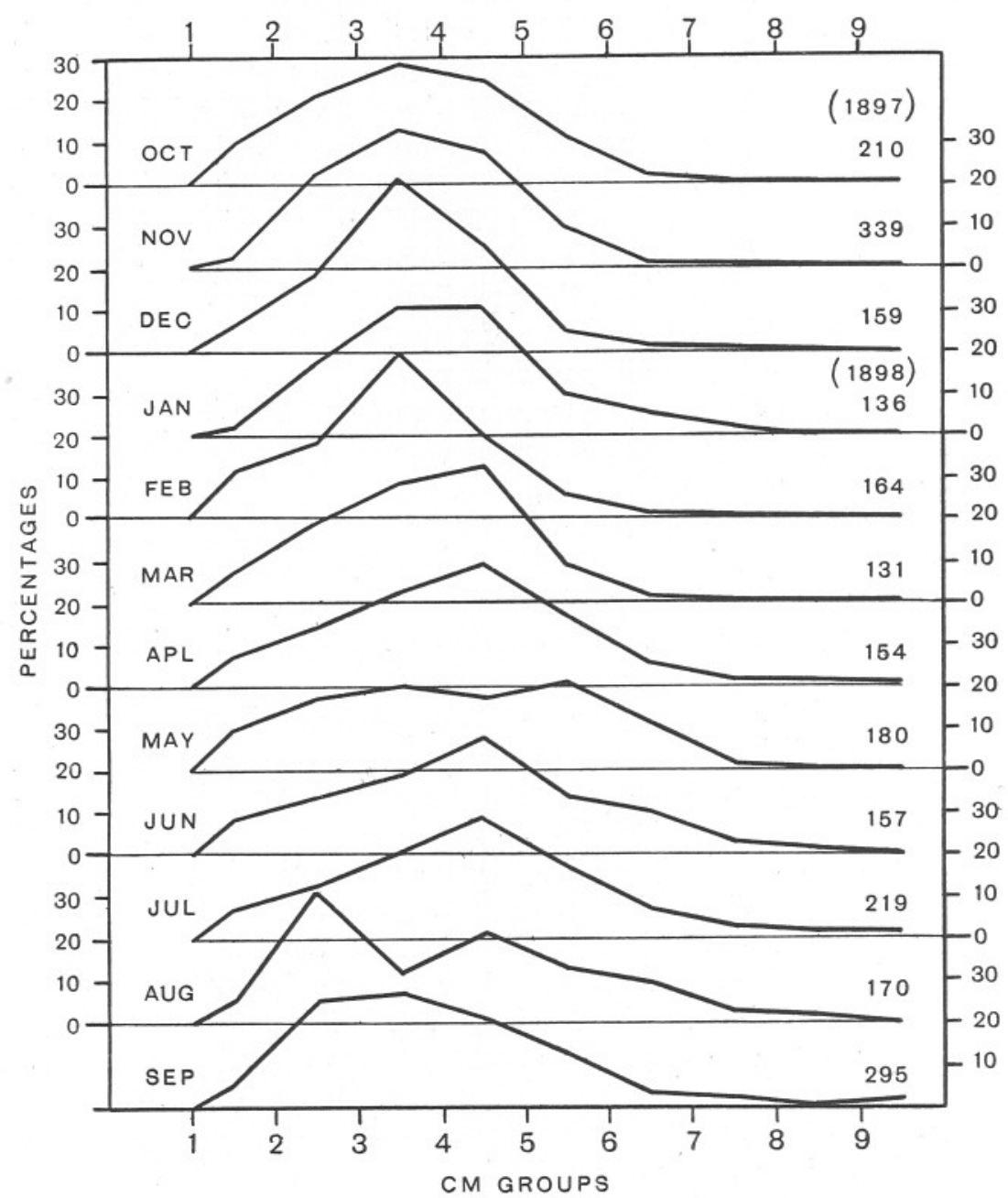

FIG. 2.-Distribution of size in monthly catches of Cancer pagurus taken on the beach at Dunbar by H. C. Williamson (15). The sizes are collected into $\mathrm{cm}$. groups and graphed as group percentages.

growth among those crabs which begin larval life and settle early in the season. The problem is complicated by the habit of inshore migration known to occur in sexually mature crabs after winter and possibly adopted in a lesser degree by adolescent crabs. 
From Williamson's observations, and Lebour's and the writer's experiments, there can be little doubt that Cancer pagurus attains a modal size of about $3.5 \mathrm{~cm}$. (carapace breadth) at the end of the first summer of growth. Williamson's work also indicates that at an age of one year the

\section{TABLE $V$.}

Numbers of Cancer pagurus (GIVEN IN CM. GROUPS) TAKEN ON THE Beach at Dunbar and in Creels just below Low Water by H. C. Williamson.

Percentages in em. groups of beach crabs are also given in italics, with totals of monthly collections in brackets.

\begin{tabular}{|c|c|c|c|c|c|c|c|c|c|c|c|c|}
\hline \multicolumn{2}{|c|}{ Cm. groups. } & $\begin{array}{c}1 \cdot 1 \\
\text { to } 2\end{array}$ & $\begin{array}{l}2 \cdot 1 \\
\text { to } 3\end{array}$ & $\begin{array}{l}3 \cdot 1 \\
\text { to } 4\end{array}$ & $\begin{array}{l}4 \cdot 1 \\
\text { to } 5\end{array}$ & $\begin{array}{c}5 \cdot 1 \\
\text { to } 6\end{array}$ & $\begin{array}{l}6 \cdot 1 \\
\text { to } 7\end{array}$ & $\begin{array}{c}7 \cdot 1 \\
\text { to } 8\end{array}$ & $\begin{array}{c}8 \cdot 1 \\
\text { to } 9\end{array}$ & $\begin{array}{c}9 \cdot 1 \\
\text { to } 10\end{array}$ & $\begin{array}{l}10 \cdot 1 \\
\text { to } 11\end{array}$ & $\begin{array}{c}11 \cdot 1 \\
\text { to } 12\end{array}$ \\
\hline et. beach & 1897 & 20 & 45 & 61 & 53 & 24 & 5 & 1 & 1 & 0 & 0 & 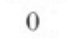 \\
\hline$(210)$ & & $9 \cdot 5$ & $21 \cdot 4$ & $29 \cdot 0$ & $25 \cdot 2$ & $11 \cdot 4$ & 2.4 & $0 \cdot 5$ & 0.5 & 0.0 & 0.0 & $0 \cdot 0$ \\
\hline beach & & 10 & 77 & 113 & 96 & 33 & 5 & 4 & 0 & 1 & 0 & 0 \\
\hline$(339)$ & & $2 \cdot 9$ & $22 \cdot 7$ & $33 \cdot 3$ & $28 \cdot 3$ & $9 \cdot 7$ & 1.5 & $1 \cdot 2$ & 0.0 & 0.3 & 0.0 & 0.0 \\
\hline beach & & 10 & 29 & 65 & 41 & 8 & 3 & 2 & 1 & 0 & 0 & 0 \\
\hline$(159)$ & & $6 \cdot 3$ & $18 \cdot 2$ & $40 \cdot 9$ & $25 \cdot 8$ & $5 \cdot 0$ & 1.9 & $1 \cdot 3$ & $0 \cdot 6$ & 0.0 & 0.0 & 0.0 \\
\hline beach & 1898 & 3 & 24 & 42 & 42 & 14 & 8 & 3 & 0 & 0 & 0 & 0 \\
\hline$(136)$ & & $2 \cdot 2$ & $17 \cdot 6$ & 30.9 & 30.9 & $10 \cdot 3$ & 5.9 & $2 \cdot 2$ & 0.0 & $0 \cdot 0$ & $0 \cdot 0$ & $0 \cdot 0$ \\
\hline beach & & 18 & 31 & 65 & 34 & 10 & 3 & 2 & 0 & 1 & 0 & 0 \\
\hline$(164)$ & & $11 \cdot 0$ & $18 \cdot 9$ & $39 \cdot 6$ & $20 \%$ & $6 \cdot 1$ & $1 \cdot 8$ & 1.2 & 0.0 & 0.6 & $0 \cdot 0$ & 0.0 \\
\hline arch beach & & 10 & 25 & 37 & 42 & 13 & 2 & 1 & 0 & 1 & 0 & 0 \\
\hline (131) & & $7 \cdot 6$ & $19 \cdot 1$ & $28 \cdot 2$ & 32.1 & $9 \cdot 9$ & 1.5 & 0.8 & $0 \cdot 0$ & 0.8 & 0.0 & 0.0 \\
\hline creel & 1901 & 0 & 0 & 1 & 1 & 5 & 3 & 2 & 0 & 2 & 1 & 1 \\
\hline beach & 1898 & 11 & 22 & 34 & 45 & 27 & 8 & 3 & 3 & 1 & 0 & 0 \\
\hline (154) & & $7 \cdot 1$ & $14 \cdot 3$ & $22 \cdot 1$ & $29 \cdot 2$ & 17.5 & $5 \cdot 2$ & 1.9 & 1.9 & 0.6 & 0.0 & $0 \cdot 0$ \\
\hline creel & 1901 & 0 & 0 & 0 & 0 & 1 & 0 & 4 & 4 & 4 & 1 & 5 \\
\hline beach & 1898 & 18 & 32 & 36 & 31 & 38 & 21 & 3 & 1 & 0 & 0 & 0 \\
\hline$(180)$ & & $10 \cdot 0^{\circ}$ & $17 \cdot 8$ & $20 \cdot 0$ & $17 \cdot 2$ & $21 \cdot 1$ & $11 . \%$ & $1 \cdot 7$ & 0.6 & 0.0 & 0.0 & 0.0 \\
\hline creel & 1901 & 0 & 0 & 0 & 5 & 6 & 19 & 32 & 23 & 18 & 15 & 29 \\
\hline beach & 1898 & 13 & 22 & 30 & 44 & 22 & 16 & 6 & 3 & 1 & 0 & 0 \\
\hline$(157)$ & & $8 \cdot 3$ & $14 \cdot 0$ & $19 \cdot 1$ & 28.0 & 14.0 & $10 \cdot 2$ & $3 \cdot 8$ & 1.9 & 0.6 & 0.0 & 0.0 \\
\hline creel & 1901 & 0 & 0 & 0 & 0 & 4 & 3 & 5 & 13 & 14 & 39 & 30 \\
\hline creel & 1900 & 0 & 0 & 0 & 0 & 2 & 20 & 32 & 44 & 35 & 25 & 19 \\
\hline beach & 1898 & 16 & 28 & 46 & 63 & 38 & 16 & 8 & 2 & 2 & 0 & 0 \\
\hline (219) & & $7 \cdot 3$ & 12.8 & $21 \cdot 0$ & 28.8 & $17 \cdot 4$ & $7 \cdot 3$ & $3 \cdot 7$ & 0.9 & 0.9 & 0.0 & 0.0 \\
\hline creel & 1901 & 0 & 0 & 0 & 1 & 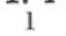 & 0 & 3 & 2 & 9 & 10 & 8 \\
\hline & 1900 & 0 & 0 & 0 & 1 & 5 & 18 & 43 & 36 & 45 & 53 & 50 \\
\hline beach & 1898 & 10 & 54 & 21 & 37 & 23 & 17 & 4 & 4 & 0 & 0 & 0 \\
\hline$(170)$ & & $5 \cdot 9$ & 31.8 & 12.4 & 21.8 & 13.5 & $10 \cdot 0$ & $2 \cdot 4$ & $2 \cdot 4$ & 0.0 & 0.0 & 0.0 \\
\hline \multirow{3}{*}{$\begin{array}{l}\text { ereel } \\
\text { beach } \\
(295)\end{array}$} & 1900 & 0 & 0 & 1 & 2 & 8 & 10 & 24 & 22 & 26 & 18 & 23 \\
\hline & 1898 & 16 & 75 & 81 & 61 & 38 & 10 & 8 & 2 & 4 & 0 & 0 \\
\hline & & $5 \cdot 4$ & 25.4 & $2 \% \cdot 5$ & $20 \%$ & 12.9 & $3 \cdot 4$ & $2 \cdot 7$ & $0 \cdot 7$ & $1 \cdot 4$ & $0 \cdot 0$ & 0.0 \\
\hline
\end{tabular}

crabs have a minimal modal value for carapace breadth of about $4.5 \mathrm{~cm}$. ; but that the indications of an offshore migration about May, along with the experimental record of the attainment of a carapace breadth of $5 \cdot 7 \mathrm{~cm}$. almost certainly in about one year, render it possible that the modal value at an age of one year may lie between 5 and $6 \mathrm{~cm}$. Definite experiments on rate of growth are required to obtain further information on 
this problem. The estimates of rate of growth given by Pearson (11) admittedly tentatively on the basis of growth in Waddington's aquariumbred crabs (15) are out of harmony with facts from the wild. On the basis of a modal value for carapace breadth of 4.5 to $5.5 \mathrm{~cm}$. in the first year of growth, continued rapid growth may be predicted until the attainment of sexual maturity at a breadth of about $4 \frac{1}{2}$ to $5 \frac{1}{2}$ inches $=11 \cdot 4$ to $14 \cdot 0 \mathrm{~cm}$. (12). If such rapid accelerative growth occurs in Cancer as in other marine animals, e.g. oyster (10), herring (1), lobster (2), it is not impossible that the edible crab may become sexually mature in about three years, for dimensions may be doubled in the second year, and very nearly the same increment in dimensions may obtain in the third year before the attainment of maturity. In Havinga's graph of increase in length of the lobster, Homarus vulgaris, the increments in length in the second and third years are each greater than the actual length at the end of the first year. Elmhirst's graph (12), which includes all observations, gives lower increments, as perhaps might be expected from the inclusion of all aquarium and pond-bred animals. In this respect it is noteworthy that a plotting of Williamson's crabs taken just below low water does give an indication of a modal value of edible crabs of 8 to $9 \mathrm{~cm}$. in the months of June and July, which would rise rapidly with a single general moult. Further investigations may show that these are second year crabs.

\section{AdDendum.}

Since the foregoing account was submitted for publication it has been found that MacKay and Weymouth in a recent publication (4) have investigated growth in the Pacific crab (Cancer magister), from mainly southern British Columbia, by a study of moults and moulting with tagging and size-frequencies. They state that "it seems possible sex-maturity may be attained by some crabs as early as the third year and in some as late as the sixth year, but that normally crabs become mature in their fourth and fifth years." Mean carapace width at an age of "one year" is estimated at a little over $1 \mathrm{~cm}$., at two years about $6 \mathrm{~cm}$., at three years a little over $8 \mathrm{~cm}$., and at four years on the attainment of sexual maturity a little over $10 \mathrm{~cm}$. The length-breadth relation and general form of C. magister is closely similar to that of C. pagurus, and MacKay and Weymouth consider that growth in the latter would appear to be essentially similar to that of $C$. magister. These authors give percentage size distribution of live crabs for the months of April to September and remark " in September, three year groups may be distinguished; the young of the year at 1 or $2 \mathrm{~cm}$., of the preceding year 4 to $7 \mathrm{~cm}$., and of the second season previous, less clearly, at about 10 to $12 \mathrm{~cm}$."

It is clear from this statement and their reconstruction of the life- 
history in a growth-curve (Fig. 6, loc. cit.) that the authors use the term "year" to mean the first summer of growth and not actually a year of twelve months, as they record "Megalops appear during July-August; 1st post-larval crabs during August," and so on. Therefore, their 1-year group would -in accordance with common European practice-be the 0-year group.

When these facts are considered the work of MacKay and Weymouth indicates that the deductions made from the experimental and observed facts on Cancer pagurus are closely comparable to those made on $C$. magister, and that $C$. pagurus may therefore very probably be sexually mature at an age of about three calendar years.

\section{ACKNOWLEDGMents.}

Most of the experiments herein recorded were carried out as researches controlled from Plymouth by the Marine Biological Association of the United Kingdom. The experiments at West Mersea were conducted on the oyster beds and with the courteous permission of the Tollesbury and Mersea Native Oyster Company.

The Morecambe Bay experiment, from which results were obtained incidentally, was financed partly by Liverpool University Joint Research Committee and partly by the Lancashire and Western Sea-Fisheries Committee. My thanks are gladly tendered to these bodies and to Miss H. M. Lewis, B.A., Mr. L. French, Mr. Wm. Searle, Mr. J. Kingcombe, Mr. P. Bond and Mr. T. Wilson for valued assistance in various respects.

\section{SUMMARY.}

From experiments in the sea with wire cages and boxes with perforated zinc sides and tops more than 100 individuals of certain Crustacea which had grown inside the apparatus have been obtained at various subsequent dates.

Minimal mean rates of growth are obtainable from the difference between maximum size at immediate entry and size at a given later date, and the approximate age by an allowance for age at entry plus the maximum time occupiable in the experimental apparatus. It was found that $C$. maenas spawned early in the year may attain a carapace width of 30 to $40 \mathrm{~mm}$. by the following winter. In experiments extending over twelve months from July to July male C. maenas attained a carapace width of 43 to $53 \mathrm{~mm}$. and females $37 \mathrm{~mm}$. at an estimated maximum age of 15 months.

In other experiments female $C$. maenas attained a carapace width of $44.6 \mathrm{~mm}$. in at most 16 months and occurred in berry at this size at a 
maximum age of about 21 months. It is inferred that female $C$. maenas become sexually mature in little more than 12 months at a carapace width of about $45 \mathrm{~mm}$. or less and that males are mature at about the same age and size or less, and appear to grow more quickly than females.

Portunus puber and $P$. corrugatus appear to have rates of growth comparable with that of $C$. maenas.

Cancer pagurus grew from a carapace width of 17.5 to $57 \mathrm{~mm}$. in at most $10 \frac{1}{4}$ months in one experiment and from $21 \mathrm{~mm}$. to $49 \cdot 7$ (female) and $47 \cdot 4$ (male) $\mathrm{mm}$. in at most 12 months in another experiment. These results are discussed in relation to other investigations on rate of growth in this species, and the conclusion reached that a carapace width of 4.5 to $5.5 \mathrm{~cm}$. may be commonly and normally attained at an age of one year, and that by increments in growth in the second and third years equal or sub-equal to that in the first become sexually mature at about three years old.

It is suggested that similar ad hoc experiments might add much to knowledge on rate of growth of Crustacea.

\section{REFERENCES.}

1. Ford, E. An account of herring investigations. Journ. Mar. Biol. Assoc., N.S., Vol. XIX, 1933.

2. Havinga, B. Krebse und Weichtiere. Handbuch der Seefischerei Nordeuropas, 3, 2, 1929, Stuttgart.

3. Lebour, M. V. The larval stages of the Plymouth Brachyura. Proc. Zool. Soc. London, pp. 491, 518, 1928.

4. MacKay, D. C. G., and Weymouth, F. W. The growth of the Pacific edible crab, Cancer magister, Dana. Journ. Biol. Board Canada, Vol. I, No. 3, 1935.

5. ORton, J. H. Preliminary account of a contribution to an Evaluation of the Sea. Journ. Mar. Biol. Assoc., N.S., Vol. X, p. 318, 1914.

6. - On the rate of growth of Cardium edule. Part I. Experimental observations. Ibid., Vol. XIV, No. 2, pp. 277, 243, 1926.

7. — Experiments in the sea on the growth-inhibitive and preservative value of poisonous paints and other substances. Ibid., Vol. XVI, No. 2, pp. 390 and 396, and Fig. 9, 1930.

8. _ - Observations and experiments on sex-change in the European Oyster $(O$. edulis). Part III. On the fate of unspawned ova. Part IV. On the change from male to female. Ibid., Vol. XIX, No. 1, pp. 17, 19-21, 1933. 
9. Orton, J. H. Bionomical Studies on Cardium edule. James Johnstone Memorial Volume, Liverpool, 1934.

10. — Laws of shell-growth in English native oysters. Nature, Vol. 135, p. 340, 1935.

11. Pearson, J. Cancer. L.M.B.C. Memoir, No. 16, 1908, Liverpool.

12. — Interdepartmental Committee on crabs and lobsters. H.M.S.O. London, 1930.

13. Shen, C. J. An investigation of the post-larval development of the shore-crab, Carcinus maenas, with special reference to the external secondary sexual characters. Proc. Zool. Soc. London, i, pp. 1-23, 1935.

14. Williamson, H. C. On the larval and early young stages and rate of growth of the shore crab Carcinus maenas. 21st Ann. Rep. Fishery Board Scotland, Pt. III, Sci. Invest., pp. 136-179, 1903.

15. Contributions to the life-histories of the edible crab (Cancer pagurus) and of other Decapod Crustacea. 22nd Ann. Rep. (1903) Fishery Board Scotland, Pt. III, Sci. Invest., p. 100, 1904. 


\title{
Variations in the White Pigment of the Eye in Gammarus cheureuxi Sexton, with a Description of a New Genetic Type, the "Clotted eye."
}

\author{
By \\ E. W, Sexton and A, R. Clark. \\ From the Plymouth Laboratory.
}

With 1 Figure in the Text.

A GREAT number of variations from the normal type have occurred in Gammarus chevreuxi during the course of the work carried out from 1912 until now.

In reviewing these variations it is convenient to class them according to the parts affected:

(1) Pigmentation of the body (3, p. 194).

(2) The Red retinal pigment of the eye (4, pp. 45-52).

(3) The Black retinal pigment of the eye.

(4) The white accessory pigment of the eye (2, p. 350).

(5) The structure of the eye, involving also the structure of the head (1, p. $274 ; 6$, pp. 356-369).

The two last classes are dealt with in this paper.

(4). Variations affecting the White Pigment of the Eye.

In the normal type (Fig. 1, a) the eye is of compound structure, sessile, non-facetted, convex, reniform in shape with the margin entire and clearly defined. It is composed of rows of ommatidia each consisting of a two-celled cone, and five retinal cells arranged round a central axis, the rhabdome. The coloured pigment is contained in the retinal cells. The interstices between the ommatidia are filled with the so-called "accessory" cells containing the opaque* white-pigment which gives the effect, in the living animal, of a regularly spaced, chalky white reticulation spread over the eye, with the ommatidia showing through the meshes as shining black spots.

* The two kinds of pigment, retinal and inter-ommatidial, differ in origin and in constitution. The eyes are usually described in terms of retinal colours, such as Black, White, Red, Purple, or Lilac, so, in order to avoid any confusion, particularly with the White Eye, the inter-ommatidial white accessory pigment is designated in this paper by the hyphenated term " white-pigment." 